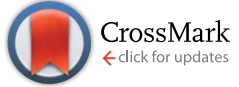

Cite this: RSC Adv., 2016, 6, 97430

\title{
Lithium salt-nonionic surfactant lyotropic liquid crystalline gel-electrolytes with redox couple for dye sensitized solar cells $\dagger$
}

\author{
Ezgi Yılmaz, ${ }^{a}$ Elif Berna Olutaş, ${ }^{\text {ab }}$ Gözde Barım, ${ }^{\text {a Jayasundera Bandarac }}$ \\ and Ömer Dag ${ }^{\star a}$
}

Lithium salt ( $\mathrm{LiCl}, \mathrm{LiBr}$, $\mathrm{Lil}$, or $\mathrm{LiNO}_{3}$ ) and a non-ionic surfactant (such as 10 -lauryl ether, $\mathrm{C}_{12} \mathrm{E}_{10}$ ) form lyotropic liquid crystalline (LLC) mesophases in the presence of a small amount of water. The mesophases can be prepared as gels by mixing all the ingredients in one pot or in the solution phase that they can be prepared by coating over any substrate where the LLC phase is formed by evaporating excess solvent. The second method is easier and produces the same mesophase as the first method. A typical composition of the LLC phases consists of 2-3 water per salt species depending on the counter anion. The Lil $-\mathrm{C}_{12} \mathrm{E}_{10}$ mesophases can also be prepared by adding $\mathrm{I}_{2}$ to the media to introduce an $\mathrm{I}^{-} / \mathrm{I}_{3}{ }^{-}$ redox couple that may be used as a gel-electrolyte in a dye-sensitized solar cell. Even though the mesophases contain a large amount of water in the media, this does not affect the cell performance. The water molecules in the mesophase are in the hydration sphere of the ions and do not act like bulk water, which is harmful to the anode of the dye-sensitized solar cells (DSSC). There are two major drawbacks of the salt-surfactant LLC mesophases in the DSSCs; one is the diffusion of the gels into the pores of the anode electrode and the other is the low ionic conductivity. The first issue was partially overcome by introducing the gel content as a solution and the gelation was carried in/over the pores of the dye modified titania films. To increase the ionic conductivity of the gels, other salts (such as $\mathrm{LiCl}$, $\mathrm{LiBr}$, and $\mathrm{LiNO}_{3}$ ) with better ionic conductivity were added to the media, however, those gels behave less effectively than pure Lil// 2 systems. Overall, the DSSCs constructed using the LLC electrolyte display high short circuit current $\left(I_{\mathrm{sc}}\right.$ of around $\left.10 \mathrm{~mA}\right)$, high open circuit voltage $\left(V_{\text {oc }}\right.$ of $\left.0.81 \mathrm{~V}\right)$ and good fill factor (0.69) and good efficiency (3.3\%). There is still room for improvement in addressing the above issues in order to enhance the cell efficiency by developing new methods of introducing the gel-electrolytes into the mesopores of the anode electrode.

Received 7th August 2016

Accepted 4th October 2016

DOI: 10.1039/c6ra19979h

www.rsc.org/advances

\section{Introduction}

Clean and renewable energy sources are some of the most investigated academic and industrial research topics in both fundamental and applied sciences. ${ }^{1}$ Converting solar energy to electrical or chemical energy is a desirable goal in these investigations. Also included in this category are solar cells and many studies have been undertaken whose goals include the

${ }^{a}$ Bilkent University, Department of Chemistry, 06800, Ankara, Turkey.E-mail: dag@ fen.bilkent.edu.tr

${ }^{b}$ Abant Izzet Baysal University, Department of Chemistry, 14030, Bolu, Turkey

${ }^{c}$ National Institute of Fundamental Studies, Hantana Road, Kandy, CP20000, Sri Lanka

$\dagger$ Electronic supplementary information (ESI) available: ATR-FTIR spectra of G2-LiCl-2, G2-LiBr-2, G2-LiI-2, and G2-LiNO ${ }_{3}-2$, ATR-FTIR spectrum and XRD pattern of mesocrystals of G2-LiI- $\mathrm{I}_{2}-4, \mathrm{UV}$-vis absorption spectra of G2-LiI- $\mathrm{I}_{2}-x$ ( $x$ is $1,2,3,4$, and 5) and LiI- $\mathrm{I}_{2}$ mixture in ethanol, water, acetonitrile and glycol Raman spectra of G2-LiI-2 and G2-LiI-I ${ }_{2}-2$, IPCE and time dependent IV curves. See DOI: 10.1039/c6ra19979h development of new types of solar cells or improvement of the existing cells. ${ }^{2-15}$ One important category of cells includes photo-electrochemical cells, which use an anode, a cathode and an electrolyte. The anode is usually fabricated using a transparent fluoride doped tin dioxide (FTO) conductor, $\mathrm{TiO}_{2}$ nanocrystal paste and a sensitizer for the absorption of solar spectrum. The sensitizers are usually dye molecules ${ }^{2-10}$ or quantum dots ${ }^{11-15}$ that absorb light to produce photo-generated electrons..$^{2-15} \mathrm{Ru}$ based dyes are the most commonly used dyes that can anchor to the titania surface and easily transfer the photo-generated electrons to the titania host. The counter electrode is usually Pt nanoparticles dispersed over FTO glass, and used for the other half-cell reaction. The third component of the cell is the electrolyte, between the two electrodes. The most efficient dye sensitized solar cell (DSSC) uses $\mathrm{I}^{-} / \mathrm{I}_{2}$ couple in acetonitrile, where $\mathrm{I}^{-} / \mathrm{I}_{3}{ }^{-}$is the active redox couple. It is important to note that the reaction between $\mathrm{I}^{-}$ion and $\mathrm{I}_{2}$ favors the formation of $\mathrm{I}_{3}{ }^{-}$ion in the acetonitrile solution. As well the half-cell potential of the $\mathrm{I}^{-} / \mathrm{I}_{3}{ }^{-}$couple is favored in acetonitrile 
solution for a larger open circuit voltage $\left(V_{\text {oc }}\right)$. The cell parameters of the DSSCs, such as $V_{\text {oc }}$ and fill factor (FF) are quite high in acetonitrile based electrolytes. ${ }^{10}$ However; these parameters are reduced in water based electrolytes. ${ }^{16-24}$ Water as a media for the electrolyte is also problematic for the dye molecules, which can be leached out from the titania surface through ligand exchange mechanism. However, there is a tremendous effort in the literature to overcome the issues in the use of water based electrolytes. ${ }^{16-24}$ Furthermore, the use of liquid electrolytes introduces problems in practical applications; such as the volatility of the solvent, leakage issues, etc. Much research focused on the use of liquid crystalline gel electrolytes in DSSCs. ${ }^{25-31}$ However, most gel phases have limited solubility towards salts and particularly for the $\mathrm{I}^{-} / \mathrm{I}_{2}$ redox couple. ${ }^{26}$

The use of salt-surfactant lyotropic liquid crystalline mesophases ${ }^{32-36}$ with the $\mathrm{I}^{-} / \mathrm{I}_{3}{ }^{-}$redox couple as gel-electrolytes could be an excellent solution. However, most lyotropic liquid crystalline (LLC) phases are formed with the help of a solvent that is also volatile, and they have very limited ionic conductivity due to low concentration of the redox couples and other ionic species. ${ }^{25-31}$ The solvent, in the LLC mesophase, can also create uncertainty in the cells. Therefore, it is important to form stable and highly conductive mesophases as gel electrolytes, where the volatility is not an issue. ${ }^{32-36}$

Recently, we have discovered a new LLC phase that can be formed by using lithium salts ( $\mathrm{LiCl}, \mathrm{LiBr}, \mathrm{LiI}, \mathrm{LiNO}_{3}$, and $\mathrm{LiClO}_{4}$ ) and water together with non-ionic surfactants. ${ }^{34-36}$ The salt-surfactant mesophases are stable under ambient conditions, in that the amount of water in the media remains constant. ${ }^{34-36}$ The driving force in the formation of the saltsurfactant mesophases is the hygroscopicity of the salts, which absorb enough water to get solvated in the hydrophilic domains of the mesophase with a much smaller amount of water. ${ }^{32-36}$ Note that the confinement effect is effective to enhance the solubility and reduce the melting point of the salts in the LLC mesophase..$^{32-36}$ Therefore any of these mesophases can be used as a gel electrolyte by adding the redox couple in the media.

In this contribution, we show the phase behavior, electrical and thermal properties of lithium salt ( $\mathrm{LiI}, \mathrm{LiBr}, \mathrm{LiCl}$, and $\mathrm{LiNO}_{3}$ )-surfactant LLC mesophases in absence/presence of LiI/ $\mathrm{I}_{2}$ under various conditions and their cell performance in a DSSC.

\section{Results and discussion}

In this investigation, we have prepared salt-surfactant LLC mesophases as gels by simply mixing salt, surfactant and a small amount of water and dilute solutions. The solution phase could be further treated to evaporate the excess solvent from the media to form the mesophases. Both sets of samples were characterized by using XRD, POM, AC conductivity, Raman, FT-IR, and UV-vis absorption spectroscopy techniques. We have found that both gels, obtained from above two methods, have identical compositions with similar structural, thermal and electrical behaviors. The gels, prepared using the salt, surfactant and sufficient amount of water (see latter, denoted as G1), require high temperatures and long duration to produce homogeneous mesophases. However, the gel samples

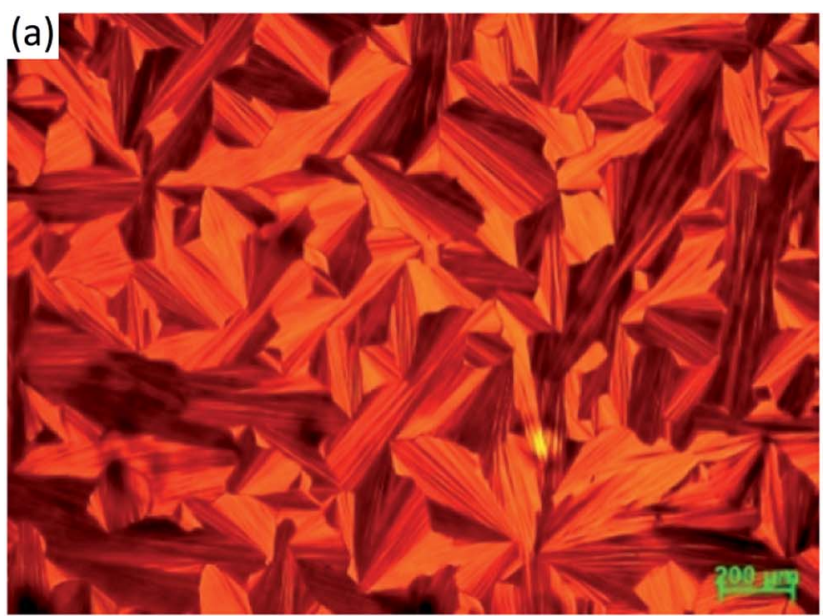

(b)

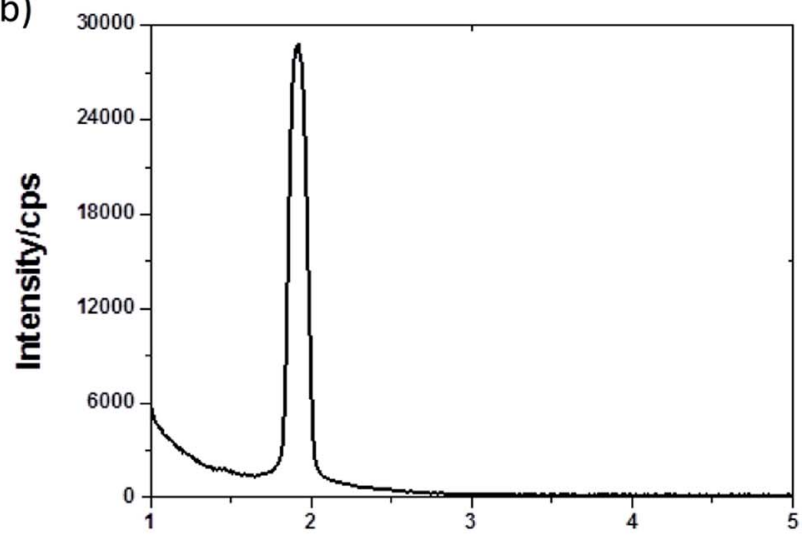

$2 \Theta$

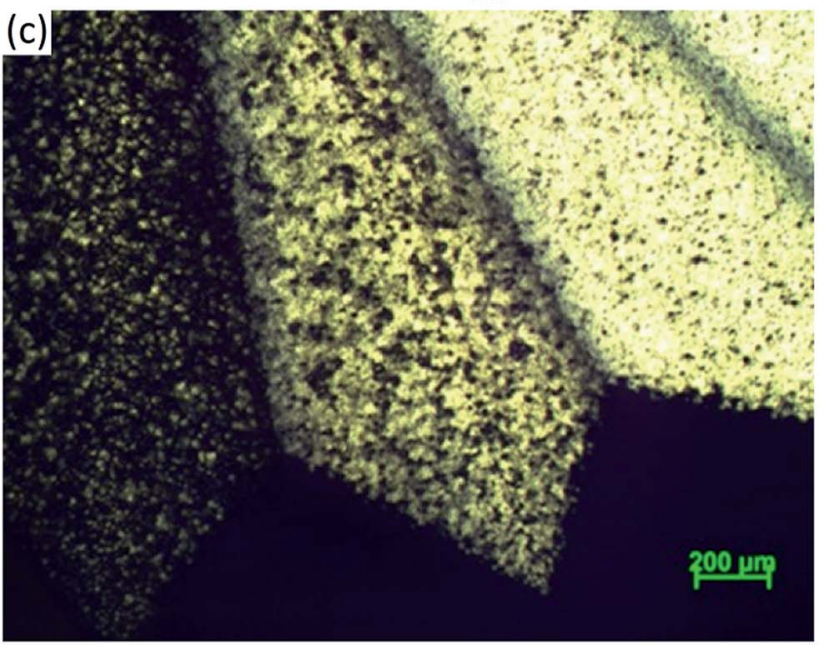

Fig. 1 Sample G1-Lil-3 with $9 \mathrm{H}_{2} \mathrm{O}$ : (a) POM image of the fresh sample, (b) XRD pattern of the fresh sample, and (c) POM image of the G2-Lil$\mathrm{I}_{2}-5$, prepared from $6 \mathrm{OH}_{2} \mathrm{O}$ solution.

prepared from the solutions (denoted as G2) are easy to prepare and provide very similar results to that of G1 samples. The $\mathrm{G} n$ LiX-\# notation is used throughout the text to describe the samples, where G stands for the gel (or LLC phase), $n$ is 1 and 2 depending on the preparation method (as described above), LiX is the lithium salts ( $\mathrm{X}$ is $\mathrm{Cl}^{-}, \mathrm{Br}^{-}, \mathrm{I}^{-}$, and $\left.\mathrm{NO}_{3}{ }^{-}\right)$, \# is the $\mathrm{LiX} /$ $\mathrm{C}_{12} \mathrm{E}_{10}$ mole ratio. In this investigation, we have used 4 different 


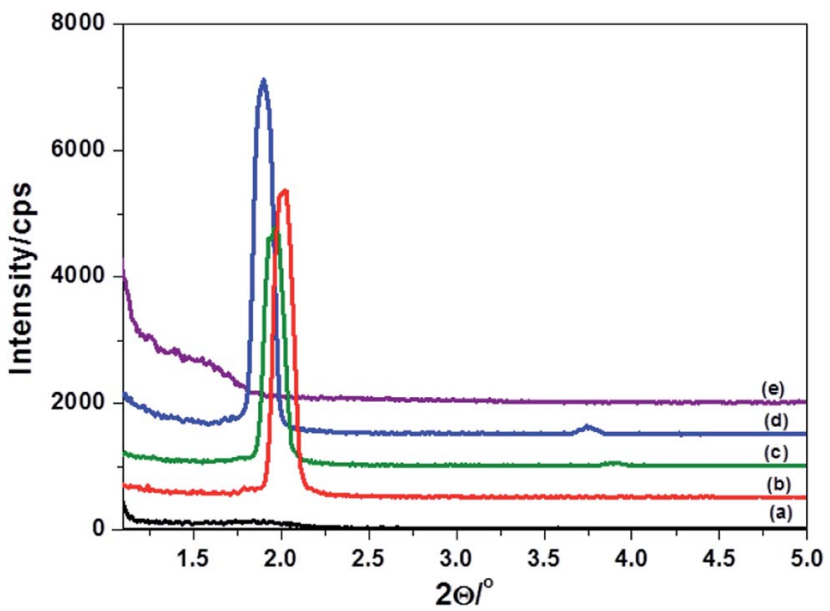

Fig. 2 Small angle XRD patterns of the G2-Lil-I ${ }_{2}$-\# (prepared with $60 \mathrm{H}_{2} \mathrm{O} / \mathrm{C}_{12} \mathrm{E}_{10}$ mole ratio) upon aging, \# values are (a) 1 , (b) 2 , (c) 3 , (d) 4 , and (e) 5 .

salts with various concentrations and also added LiI/ $\mathrm{I}_{2}$ in the media as the redox couple for the solar cell applications.

The $\mathrm{G} n$-LiCl-\#, $\mathrm{G} n$-LiBr-\#, and $\mathrm{G} n$ - $\mathrm{LiNO}_{3}-\#$ samples are in LLC mesophase in broad salt concentrations, where \# is 2-10, 28 , and $2-8$, respectively. ${ }^{34,35}$ Both sets of mesophases display focal conic fan texture, characteristic to the hexagonal phase (Fig. 1(a)) in a broad range of salt concentration and display a highly intense diffraction line at around $1.8^{\circ}, 2 \theta$, corresponding to the (100) plane of $2 \mathrm{D}$ hexagonal mesophase, Fig. 1(b). The Gn-LiI-\# samples also form LLC mesophase up to a $5 \mathrm{LiI} / \mathrm{C}_{12} \mathrm{E}_{10}$ mole ratio however the phase undergoes crystallization at a mole ratio above 3 , see Fig. $1(\mathrm{c}) .^{37}$ The addition of $\mathrm{I}_{2}$ to the media changes the viscosity and structure of the samples but if the LiI/ $\mathrm{I}_{2}$ mole ratio is kept above 10 , there is almost no detectable changes in the properties of the $\mathrm{G} n-\mathrm{LiI}-\mathrm{I}_{2}-\#$ samples, compared to the $\mathrm{I}_{2}$ free counterparts. Both G1-LiI-\# and G1-LiI$\mathrm{I}_{2}$-\# (LiI/ $\mathrm{I}_{2}$ mole ratio of 10) samples with a little water form $2 \mathrm{D}$ hexagonal phase up to $4 \mathrm{LiI} / \mathrm{C}_{12} \mathrm{E}_{10}$ mole ratio, Fig. 2, but at a mole ratio above 4 , the $\mathrm{G} n$-LiI- $\mathrm{I}_{2}-4$ mesophase also slowly transforms to a soft solid mesocrystal. ${ }^{37}$ The mesocrystal formation becomes visible around a $4 \mathrm{LiI} / \mathrm{C}_{12} \mathrm{E}_{10}$ mole ratio and enhances with an increasing amount of LiI, where at mole ratio of 5 it is difficult to keep the mixture in a LLC phase.

The lithium salt-surfactant mesophases are stable in the presence of a certain amount of water, which is highest in the $\mathrm{G} n$-LiCl-\# and lowest in the $\mathrm{G} n$ - $\mathrm{LiNO}_{3}$-\# samples. Note also that the amounts of water in the LLC mesophases are much lower than the solubility limit of these salts in an aqueous saturated solution; it is a fixed quantity and only depends on the salt type, amount, and humidity of the media. To quantify and also to identify the phase behavior of the LLC samples, a set of samples were prepared using excess water and aged under ambient conditions to evaporate the excess water; the water evaporation always stops at a certain water concentration. Usually, this process ends after a few hours, but the samples were followed for days to make sure the excess water is completely removed. Fig. 3 shows the ATR-FT-IR spectra of a series of G2-LiCl-\#
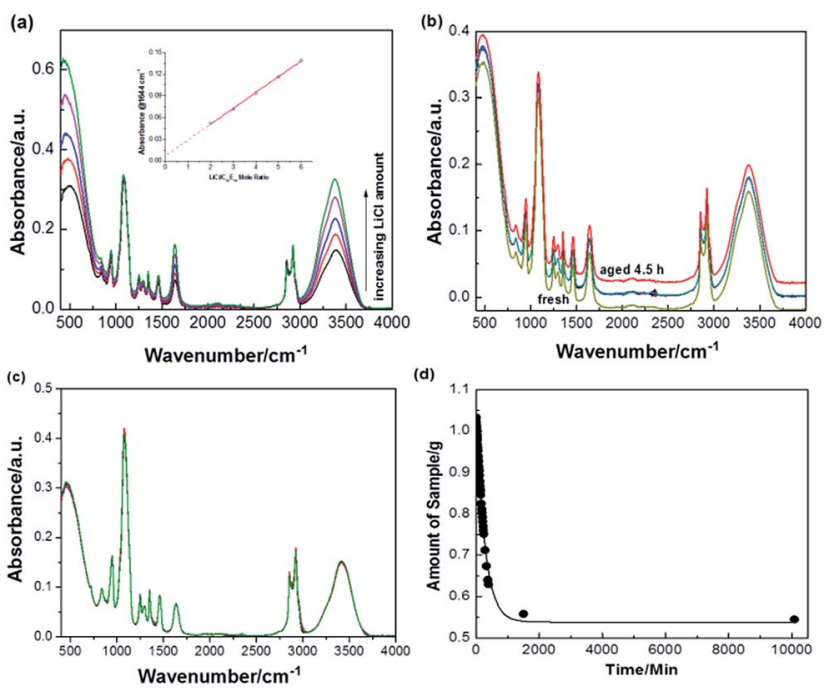

Fig. 3 ATR-FT-IR spectra of (a) G2-LiCl-\# (where \# is 2, 3, 4, 5, and 6 from bottom to top). Inset: the plot of intensity of the water bending mode of $\mathrm{G} 2-\mathrm{LiCl}$ \# versus $\mathrm{LiCl} / \mathrm{C}_{12} \mathrm{E}_{10}$ mole ratio, (b) $\mathrm{G} 1-\mathrm{LiCl}-2$ aging over time (total 20 spectra, followed for $4 \mathrm{~h} 30 \mathrm{~min}$.), (c) G1-Lil-2 prepared using 2, 3, 4, 5, and 6 water $/ \mathrm{C}_{12} \mathrm{E}_{10}$ mole ratio and recorded after $24 \mathrm{~h}$ exposure to the atmosphere (identical 5 spectra). (d) Weight versus time plot of $\mathrm{G} 2-\mathrm{Lil}-\mathrm{I}_{2}-2$ with $60 \mathrm{H}_{2} \mathrm{O} / \mathrm{C}_{12} \mathrm{E}_{10}$ mole ratio.

samples, where \# is 2, 3, 4, 5, and 6. A plot of the intensity of the water bending mode versus LiCl concentration is linear, going almost through the origin, see inset in Fig. 3. This behavior clearly shows that the only water remaining in the mesophase is the hydration water. If the appropriate amount of water is added to the media, the spectra do not change in all LiX- $\mathrm{C}_{12} \mathrm{E}_{10}$ systems during the aging process; see Fig. 3(b). Moreover, if the amount of water in the sample is lower than the critical amount, the sample absorbs ambient water, but if it is in excess, it desorbs the excess water until it reaches to a constant water/salt mole ratio, Fig. 3(c). Notice that this is an important property for LLC mesophases, which could potentially be used in various electrochemical applications as the gel-electrolytes.

The evaporation of excess water is a rapid (in a few seconds a large fraction of water evaporates) process, but it slows when the LLC mesophase forms, Fig. 3(d). Note also that the LLC phase exists over a broad water range, but it always stabilizes at a specific water amount in all salt-surfactant mesophases, where the absorption and desorption rates are equal. The first FT-IR spectra recorded from the samples are not necessarily quantitative in terms of water concentration in the $\mathrm{G} n$ samples unless the samples have been prepared using correct amount of water. It is difficult to predict the amount of water in the samples using only FT-IR spectroscopy. Therefore, the water concentrations in the samples were also determined using solutions of saltsurfactant-water and a 4 digit balance. Accordingly, we found out that around 2-3 waters per LiX are the final compositions of the G2-LiX-\# samples, where LiX is LiI, $\mathrm{LiBr}, \mathrm{LiCl}$, or $\mathrm{LiNO}_{3}$, similar to G1 samples. The FTIR spectra of the aged samples of G1 and G2 are identical. Note also that the water concentration in the stabilized LLC samples is similar in the Gn-LiX-\# (where $\mathrm{X}$ is $\mathrm{Cl}^{-}, \mathrm{Br}^{-}$, and I ${ }^{-}$), but relatively low in the $\mathrm{LiNO}_{3}$ case, Fig. $\mathrm{S} 1 . \dagger$ 
The water bending mode also provides insight into the nature of the water molecules in the mesophase, for instance it shifts from 1645 to $1630 \mathrm{~cm}^{-1}$ going from $\mathrm{Cl}^{-}$to $\mathrm{I}^{-}$, indicating that the hydroscopic anions, such as $\mathrm{I}^{-}$ion has hydrated water with less hydrogen-bonding and acts as structure breakers and the lyotropic anions, such as $\mathrm{Cl}^{-}$ion acts as structure makers (which cause the formation of bulk-like water with more hydrogen-bonding). The same behavior is also visible in the water stretching region in that the water peak is quite broad and more red-shifted in the $\mathrm{G} n$-LiCl-\# samples, but sharp and blue shifted in the Gn-LiI-\# samples, see Fig. 4. These observations are in accord with the Hofmeister effect in that $\mathrm{I}^{-}$is a hydrotropic ion and break the water structure and hydrates the surfactant domains, however, the $\mathrm{Cl}^{-}$ion is a lyotropic anion and water-structure maker, dehydrates the surfactant domains..$^{38-40}$ As a result the $\nu$-CO stretching are red-shifted in the FTIR spectra, compare the spectra in Fig. 4(b). Therefore, it is reasonable to say that the water in the Gn-LiCl LLC mesophases is bulk-like, but it is mostly hydration water in the Gn-LiI LLC phases. This is a very critical property in the use of LiI$\mathrm{C}_{12} \mathrm{E}_{10}$ LLC mesophases as gel-electrolytes, especially, if the bulk-water is an issue for the application, such as in solar cells. For instance, bulk-water, in the DSSCs, negatively affects the performance of the cell; it leaches the dye molecules from the electrode surface and drops the current generated from the cell, also affects the open circuit voltage $\left(V_{\text {oc }}\right)$ value by increasing reduction half-cell potential of the redox couple. ${ }^{24}$ Therefore, it is undesired to have bulk-like water in the gel-electrolytes in DSSCs.

$\mathrm{I}^{-} / \mathrm{I}_{3}{ }^{-}$couple has been extensively used as a redox couple in efficient DSSCs. Therefore, we also incorporated these couples into the salt-surfactant LLC mesophases. Unfortunately, the LLC mesophases of the $\mathrm{G} n$-LiI-\# are stable up to $3 \mathrm{LiI} / \mathrm{C}_{12} \mathrm{E}_{10}$ mole ratios and above which they undergo to a mesocrystallization. ${ }^{37}$ Therefore only the $\mathrm{G} n$-LiI- $\mathrm{I}_{2}$-\# samples, where \# is 1,2 , and 3 were investigated in detail. However, to demonstrate the
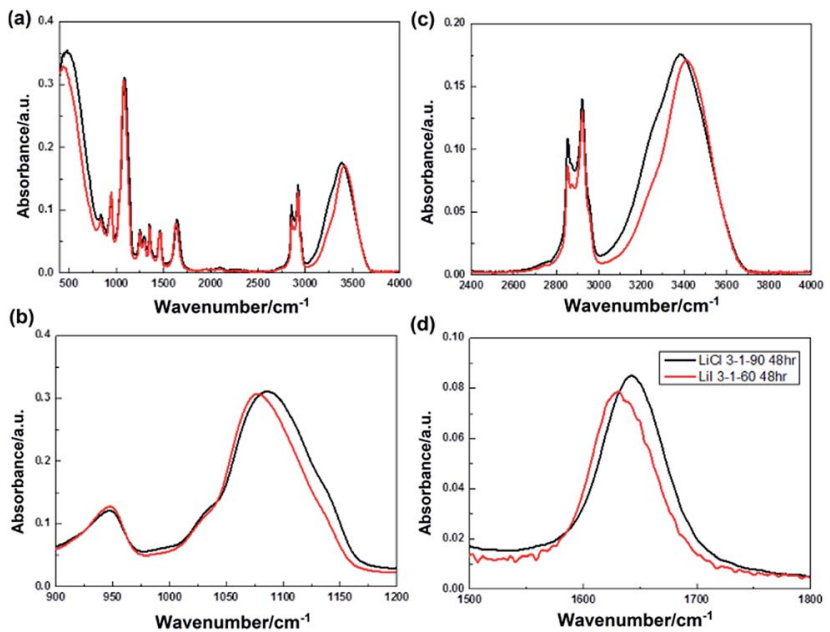

Fig. 4 Different region of the ATR-FT-IR spectra of G1-LiCl-3 and G1Lil-3 (a) all mid-IR, (b) $\nu$-CO stretching, (c) $\nu$ - $\mathrm{CH}$ (surfactant) and $\nu-\mathrm{OH}$ (water) stretching, and (d) $\delta-\mathrm{H}_{2} \mathrm{O}$ bending, regions. other compositions, the $\mathrm{G} n$-LiI- $\mathrm{I}_{2}-4$ and $\mathrm{G} n$-LiI- $\mathrm{I}_{2}-5$ samples were also prepared and analyzed. Fig. 2 shows a set of small angle diffraction patterns of these samples. The XRD patterns clearly indicate that the samples made using $\mathrm{G} n-\mathrm{LiI}-\mathrm{I}_{2}-2$ to $\mathrm{G} n$ LiI- $\mathrm{I}_{2}-4$ have sharp diffraction lines, indicating a meso-order; but the samples made using $\mathrm{G} n-\mathrm{LiI}-\mathrm{I}_{2}-1$ and $\mathrm{G} n-\mathrm{LiI}-\mathrm{I}_{2}-5$ (low and very high LiI) are quite disordered. Note also that the diffraction patterns of the samples of $\mathrm{G} n$-LiI- 4 and $\mathrm{G} n$-LiI-5 slowly change, where the small angle diffraction lines shift to smaller angles and many new wide angle lines appear overtime, due to mesocrystallization. ${ }^{37}$ The FTIR spectroscopy is even more sensitive in determining the mesocrystallization, in that even the early stage of the process can be captured. Many IR peaks of the surfactant and water become sharp and shifts upon mesocrystallization, see Fig. S2. $\dagger$ For instance, the water bending mode red shifts down to $1605 \mathrm{~cm}^{-1}$ and becomes sharper and the water stretching frequency also show some shifts and becomes sharper and more intense, in addition to the sharpening of many surfactant peaks. It is likely that the hydration sphere plays a critical role in the mesocrystallization process. The assembly of the hydrated ions in the hydrophilic domains enforces the surfactant molecules to expand through conformational changes and interact with each other more strongly to form the soft mesocrystals. ${ }^{37}$ We consider the mesocrystallization to be a problem in the DSSCs and addition of $\mathrm{I}_{2}$ to the media does not stop this process, therefore, we limited our investigation to gel-electrolytes between 1 and $3 \mathrm{LiI} / \mathrm{C}_{12} \mathrm{E}_{10}$ mole ratios with a $\mathrm{LiI} / \mathrm{I}_{2}$ mole ratio of 10 in DSSCs.

Another drawback of the water based electrolytes is the reaction between $\mathrm{I}^{-}$and $\mathrm{I}_{2}$, in that a large amount of $\mathrm{I}_{2}$ remains in the water media, which is undesired in a well performing solar cell. However, with many other solvents such as acetonitrile, the $\mathrm{I}_{3}{ }^{-}$formation is favored and it is a good solvent. To elucidate this, UV-vis absorption spectra of $\mathrm{LiI} / \mathrm{I}_{2}$ mixture in different media were recorded to compare them to the redox couple in the LLC media, see Fig. S3. $\dagger$ The band at $522 \mathrm{~nm}$ is due to $I_{2}$ in the samples and is clearly visible with water, but absent with other solvents and in all $\mathrm{G} n$-LiI- $\mathrm{I}_{2}$ mesophases, see Fig. S3. $\dagger$ The sharp and intense peaks, at 362 and $292 \mathrm{~nm}$, originate from the $\mathrm{I}_{3}{ }^{-}$ion. ${ }^{41}$ The Raman spectra of both Gn-LiI$I_{2}$ samples display peaks at $110,140,220$, and $330 \mathrm{~cm}^{-1}$. The Raman peaks at 110,220 , and $330 \mathrm{~cm}^{-1}$ are due to fundamental, $1^{\text {st }}$, and $2^{\text {nd }}$ overtones of the symmetric stretching of $\mathrm{I}_{3}{ }^{-}$ion, respectively. ${ }^{41}$ The shoulder at around $140 \mathrm{~cm}^{-1}$ could be asymmetric stretching of $\mathrm{I}_{3}{ }^{-}$(it is weakly observed in nonlinear $\mathrm{I}_{3}{ }^{-}$) or poly-iodide $\left(\mathrm{I}_{x}{ }^{-}, x\right.$ is 5 or higher) species that form in the presence of $I_{2}$ at high concentrations. ${ }^{42-44}$ However, the poly-iodide has also a peak at around $170 \mathrm{~cm}^{-1}$ and it is absent in our spectra, which suggest that the only poly-iodide specie in the LLC phase is triiodide. ${ }^{44}$ The UV-vis absorption spectra of the LLC phase are also consistent with the above assignment that the poly-iodide species have absorption above $600 \mathrm{~nm}$. The absence of a peak at around 170 or $210 \mathrm{~cm}^{-1}$ in the Raman spectra and $522 \mathrm{~nm}$ or higher wavelength peaks in the visible absorption spectra indicate that there is no $I_{2}$ or poly-iodide species in the LLC media (or below detection limits of Raman and UV-visible absorption spectrometers). ${ }^{44}$ The 
same Raman peaks are also weakly observed in the Gn-LiI samples, Fig. S4. $\dagger$ Both UV-vis absorption and Raman spectra collectively show that $\mathrm{I}^{-} / \mathrm{I}_{3}{ }^{-}$couple are not exposed to bulkwater in the LLC media. Note also that both $\mathrm{Li}^{+}$and $\mathrm{I}^{-}$ions are hydrotropic ions and break the water structure and hinders the bulk-water formation and are consistent with the above observations.

Both $\mathrm{G} n$-LiI- $\mathrm{I}_{2}-2$ samples were tested in DSSCs as gel electrolytes. The gels of G1 samples were directly placed over the anode (FTO-buffer-TiO ${ }_{2}$-dye) surface, covered and pressed together using the cathode (Pt nanoparticle coated FTO) electrode. The $I-V$ curve of such cell provides $1.74 \mathrm{~mA} \mathrm{~cm}^{-2}$ short circuits current, $0.42 \mathrm{~V}$ open circuit voltage, 0.58 fill factor (FF) and $0.51 \%$ cell efficiency. The low efficiency is likely due to bad electrolyte-electrode contact in the anode side. To increase the contact and enhance diffusion of the electrolyte into the mesopores of titania anode electrode, the gels were dissolved in a solvent and dropped over the electrode surface to suck the electrolyte into the pores. Finally, the excess solvent was

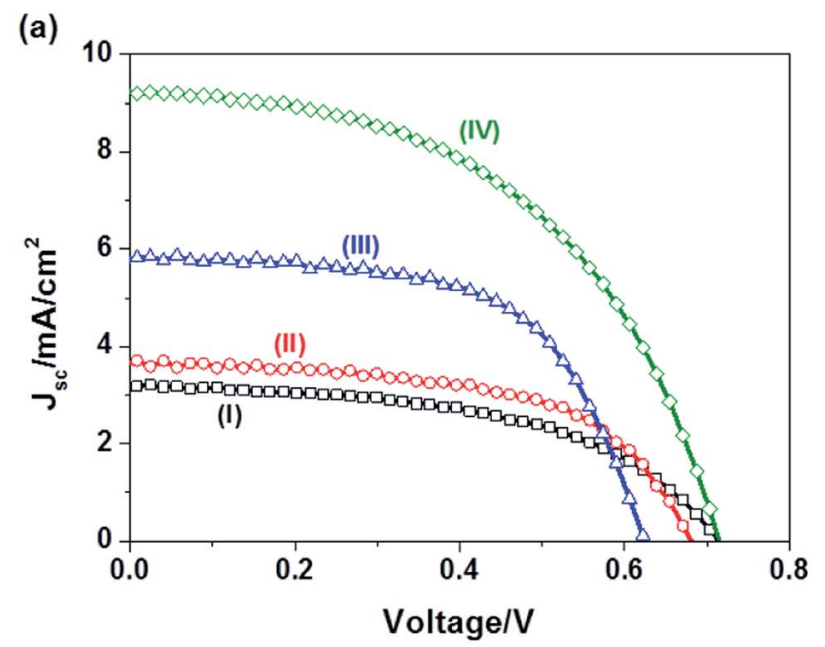

(b)

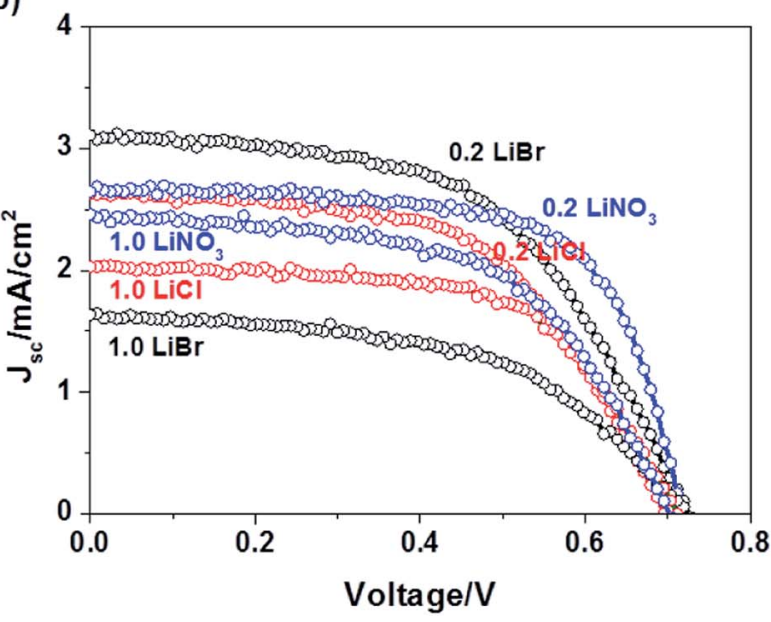

Fig. 5 I-V curves of (a) G2-Lil-I $2-2$ introduced in different solvents (I) $5 \mathrm{~g}$ ethanol, (II) $1 \mathrm{~g}$ water and $5 \mathrm{~g}$ ethanol, and (III) $0.5 \mathrm{~g}$ water and $5 \mathrm{~g}$ ethanol, (IV) G2-Lil-I $2-2$ in the presence of 4TBP and (b) G2-Lil-I $2-2$ with various amounts of $\mathrm{LiCl}, \mathrm{LiBr}$, and $\mathrm{LiNO}_{3}$ as indicated in the samples with 4TBP. evaporated to form the gels in and over the pores. This process ensures a better diffusion as well as better contact between the two electrodes. For this purpose water, ethanol, ethanol-water mixture and acetonitrile were tested as a solvent. The use of just water and surprisingly acetonitrile leach out some of the dyes and reduce the collected current. Ethanol works better than both solvents. However the strong performance was found using a mixture of ethanol and water, Fig. 5(a). As noted, not only the performance of the cells is enhanced, the open circuit voltage can also be increased up to $0.72 \mathrm{~V}$, which is unusual for water based electrolytes. In various cells, the best $I_{\mathrm{sc}}, V_{\mathrm{oc}}$, and FF values were recorded as $9.26 \mathrm{~mA} \mathrm{~cm} \mathrm{~cm}^{-2}, 0.72 \mathrm{~V}$, and 0.50 , respectively, upon the addition of $4 \mathrm{TBP}$ (4-butylpyridine) to the electrolyte solution, Fig. 5(a). 4TBP acts as surface capping agent and bind to the empty titania sites to block the direct contact of the electrolyte with a bared titania surface, where the electron transfer can take place and cause a short-cut. Even, changing the titania source improves the solar performance of the gel-electrolytes, Fig. 5(a). Therefore, there is still room to improve these values by improving the contact between the electrodes and electrolytes.

The incident photon to current efficiency (IPCE) was also measured for the optimized solar cell and shown in Fig. S6(a). $\dagger$ The IPCE spectrum of the solar cell is very well matched with the absorption spectrum of the dye N71. The nearly equal $I_{\mathrm{sc}}(9.5$ $\left.\mathrm{mA} \mathrm{cm}{ }^{-2}\right)$ from $I V$ and the estimated $I_{\mathrm{sc}}\left(10.0 \mathrm{~mA} \mathrm{~cm}{ }^{-2}\right)$ from IPCE confirms the validity of the measured solar cell performance, Fig. S6(b).†

Another drawback of G2-LiI- $\mathrm{I}_{2}-2$ is low conductivity (typical conductivity is $0.1 \mathrm{mS} \mathrm{cm} \mathrm{cm}^{-1}$ ). However, other lithium saltsurfactant mesophases have better ionic conductivity values, see Table 1. Therefore, to improve the conductivity of the G2LiI- $\mathrm{I}_{2}$ mesophases, we also prepared samples by adding various amounts of $\mathrm{LiCl}, \mathrm{LiBr}$, or $\mathrm{LiNO}_{3}$ into the $\mathrm{G} 2-\mathrm{LiI}-\mathrm{I}_{2}-2$ samples, see Table 1. Interestingly, 4-tert-butylpyridine (4TBP) is very important in the mixed salt systems. The performance of the G2-LiI- $\mathrm{I}_{2}-2-\mathrm{LiCl}$ without 4TBP electrolyte was the worst, where the efficiency drops drastically with an increasing LiCl in the media, even though the conductivity increased by 1.7 to 5 times. The presence of LiCl drops the $V_{\text {oc }}$ from 0.63 to $0.58 \mathrm{~V}$ at low concentrations $(0.2 \mathrm{LiCl})$ and to $0.29 \mathrm{~V}$ and display a very low efficiency of $0.24 \%$ at higher concentrations $(1.0 \mathrm{LiCl}) . \mathrm{LiNO}_{3}$ also behaves similarly; at low concentrations, the $I_{\mathrm{sc}}$ drops and at higher concentration, both $I_{\mathrm{sc}}$ and $V_{\mathrm{oc}}$ drop, see Table 2 and Fig. S5(a).† Notice also that the nitrate samples have the highest

Table 1 The conductivity results from the $\mathrm{G} 2-\mathrm{Lil}-\mathrm{I}_{2}-2-\mathrm{LiX}\left(\mathrm{X}=\mathrm{Cl}^{-}\right.$, $\mathrm{Br}^{-}$, and $\mathrm{NO}_{3}^{-}$) mesophases

\begin{tabular}{llll}
\hline \multirow{2}{*}{$\begin{array}{l}\text { Salt } / \mathrm{C}_{12} \mathrm{E}_{10} \text { mole } \\
\text { ratio }\end{array}$} & \multicolumn{2}{l}{ Conductivity $\left(\mathrm{mS} \mathrm{cm}^{-1}\right)$} \\
\cline { 2 - 4 } & $\mathrm{LiCl}$ & $\mathrm{LiBr}$ & $\mathrm{LiNO}_{3}$ \\
\hline 0.2 & 0.17 & 0.31 & 0.26 \\
0.4 & 0.19 & 0.36 & 0.33 \\
0.6 & 0.37 & 0.38 & 0.38 \\
0.8 & 0.44 & 0.50 & 0.57 \\
1.0 & 0.50 & 0.78 & 0.90
\end{tabular}


ionic conductivity. The effect is similar to that of LiCl system. However, in the case of $\mathrm{LiBr}$, increasing the $\mathrm{LiBr}$ in the media improves both $I_{\text {sc }}$ and $V_{\text {oc }}$ values of the DSSC, see Fig. S5(a) $\dagger$ and Table 2, but at very low LiBr concentrations, the cell is almost dead (with a recorded lowest efficiency of $0.03 \%$ ), even though the conductivity has been improved. For instance the $V_{\mathrm{oc}}, \mathrm{FF}$, and \% efficiency drops drastically, in a cell designed using $0.2 \mathrm{LiBr}$ without $4 \mathrm{TBP}$, to $0.05 \mathrm{~V}, 0.25$, and $0.03 \%$, respectively. These numbers improve in the $1.0 \mathrm{LiBr}$ samples to $0.63 \mathrm{~V}, 0.54$, and $1.68 \%$, respectively. We also measured the $I V$ curves of the cells in a long run. Fig. S6(c) $\dagger$ shows two $I V$ curves of the cell measured right after the construction and 5 months later. Both cells perform as good, showing the stability of the cell with the gel electrolytes.

In the presence of $4 \mathrm{TBP}$, even though the conductivity of the gels were improved with the addition of another lithium salt in the media, the cell performance diminished with increasing concentrations of the second salt ( $\mathrm{LiCl}, \mathrm{LiBr}$, or $\mathrm{LiNO}_{3}$ ), see Table 2 and Fig. 5(b). We also monitored the melting point of the mesophases with the addition of a second lithium salt to the media and found out that the melting point of the G2-LiI$\mathrm{I}_{2}$-2-LiX mesophase increases (from 38 to $48^{\circ} \mathrm{C}$ in $\mathrm{LiCl}, 42$ to 60 ${ }^{\circ} \mathrm{C}$ in $\mathrm{LiNO}_{3}$, and 52 to $70{ }^{\circ} \mathrm{C}$ in $\mathrm{LiBr}$ cases) with increasing the lithium salt concentration (from 0.2 to 1.0 ) in all cases. The higher melting point may affect the diffusion of the gels into the mesopores of the electrodes. A drastic drop in the collected current from the cells with the addition of the second salt could be due to a bad contact between the gel-electrolyte and anode surface. However, the $V_{\text {oc }}$ value of the DSSC can be improved if G2-LiBr-2-LiI- $\mathrm{I}_{2}\left(\mathrm{LiI} / \mathrm{C}_{12} \mathrm{E}_{10}\right.$ mole ratio of 0.7 and $\mathrm{I}_{2} /$ $\mathrm{I}^{-}$mole ratio of 0.1 , the major salt is $\mathrm{LiBr}$ ) is employed as the gel-electrolyte. A cell, designed using G2-LiBr-2-LiI- $\mathrm{I}_{2}$, provides a better $V_{\text {oc }}$ value of $0.81 \mathrm{~V}$ with a better fill factor of 0.69 , see Fig. S5. $\uparrow$ However, the gel with $2 \mathrm{LiCl}$ in place of LiBr drops the $V_{\text {oc }}$ drastically, Fig. S5(b). $\uparrow$ The presence of 4TBP in these gels levels the $V_{\mathrm{oc}}$ values in all gels, Fig. S5(c). $\dagger$ The origin of the above behaviours is not clear at this moment. Therefore, further investigations are necessary to elucidate the effect of

Table 2 Photovoltaic characteristics of the DSSCs with different electrolyte compositions ${ }^{a}$

\begin{tabular}{lllll}
\hline Solvent & $V_{\text {oc }}(\mathrm{V})$ & $J_{\text {sc }}\left(\mathrm{mA} \mathrm{cm}^{-2}\right)$ & Fill factor & \% efficiency \\
\hline $\mathrm{H}_{2} \mathrm{O}^{\mathrm{G}}$ & 0.56 & 3.37 & 0.55 & 1.00 \\
$\mathrm{C}_{2} \mathrm{H}_{5} \mathrm{OH}^{\mathrm{G}}$ & 0.64 & 4.16 & 0.60 & 1.59 \\
$\mathrm{H}_{2} \mathrm{O}+\mathrm{C}_{2} \mathrm{H}_{5} \mathrm{OH}^{\mathrm{G}}$ & 0.68 & 4.93 & 0.61 & 1.85 \\
$\mathrm{C}_{2} \mathrm{H}_{5} \mathrm{OH}^{\mathrm{S}}$ & 0.72 & 3.17 & 0.51 & 1.18 \\
$\mathrm{H}_{2} \mathrm{O}+\mathrm{C}_{2} \mathrm{H}_{5} \mathrm{OH}^{\mathrm{S}}$ & 0.63 & 5.86 & 0.60 & 2.20 \\
$4 \mathrm{TBP}^{b}$ & 0.72 & 9.26 & 0.50 & 3.33 \\
$0.2 \mathrm{LiCl}^{c}$ & $0.69 / 0.58$ & $2.64 / 5.13$ & $0.56 / 0.52$ & $1.04 / 1.55$ \\
$1.0 \mathrm{LiCl}^{c}$ & $0.71 / 0.29$ & $2.03 / 2.55$ & $0.62 / 0.33$ & $0.89 / 0.24$ \\
$0.2 \mathrm{LiNO}_{3}{ }^{c}$ & $0.72 / 0.62$ & $2.46 / 3.55$ & $0.67 / 0.46$ & $1.29 / 1.00$ \\
$1.0 \mathrm{LiNO}_{3}{ }^{c}$ & $0.70 / 0.40$ & $2.46 / 1.11$ & $0.57 / 0.47$ & $0.98 / 0.21$ \\
$0.2 \mathrm{LiBr}^{c}$ & $0.73 / 0.05$ & $3.10 / 2.58$ & $0.54 / 0.25$ & $1.22 / 0.03$ \\
$1.0 \mathrm{LiBr}^{c}$ & $0.72 / 0.63$ & $1.64 / 4.95$ & $0.53 / 0.54$ & $0.63 / 1.68$
\end{tabular}

${ }^{a} \mathrm{G}$ Solution from gel, ${ }^{\mathrm{S}}$ prepared as a solution. ${ }^{b}$ Prepared as a solution with 4TBP. ${ }^{c}$ Prepared as a solution with another LiX with/without $4 \mathrm{TBP}$, as indicated. ions on the solar performance of the $\mathrm{G} n-\mathrm{LiI}-\mathrm{I}_{2}-\mathrm{X}-\mathrm{LiX}$ mesophases.

\section{Experimental}

\section{Preparation of the $\mathrm{LiX}-\boldsymbol{x H}_{2} \mathrm{O}-\mathrm{C}_{12} \mathrm{E}_{10}$ LLC samples}

LiCl, LiBr, LiI, and $\mathrm{LiNO}_{3}$ salts were used with different amounts of water. The samples were prepared by mixing the surfactant $\left(\mathrm{C}_{12} \mathrm{E}_{10}\right)$ and lithium salts in pre-determined amounts. The surfactant amount was kept constant throughout this investigation and the amount of water and salt were varied. To prepare the gel samples, first mix quantitative amount of salt, surfactant and distilled water in a vial and then put into a heating bath to homogenize the mixture by shaking and heating simultaneously. After 24 hours of shaking at $80^{\circ} \mathrm{C}$, they were ready to be characterized and for various other uses. For instance, a sample with mole ratios of 3:9:1 for $\mathrm{LiCl}: \mathrm{H}_{2} \mathrm{O}: \mathrm{C}_{12} \mathrm{E}_{10}$ was prepared using a $0.20 \mathrm{~g}$ of LiCl salt, 0.09 $\mathrm{g}$ of $\mathrm{H}_{2} \mathrm{O}$ and $1.00 \mathrm{~g}$ of $\mathrm{C}_{12} \mathrm{E}_{10}$. All other compositions were prepared using the same method by varying the amount of salt and water.

\section{Preparation of the gel electrolytes with $\mathrm{I}^{-} / \mathrm{I}_{3}{ }^{-}$redox couple}

LiI salt and $\mathrm{I}_{2}$ were used as a redox couple for solar cell measurements. $0.46 \mathrm{~g}$ of distilled water was used for all gel electrolytes and the ratio of $\mathrm{LiI} / \mathrm{C}_{12} \mathrm{E}_{10}$ and $\mathrm{I}_{2}: \mathrm{C}_{12} \mathrm{E}_{10}$ were 2.0 and 0.2 , respectively. Moreover, 1 to $0.1,3$ to 0.3 , and 4 to 0.4 (LiI to $\mathrm{I}_{2}$ mole ratio, respectively) were also prepared using varying amounts of water. For instance, to prepare $2 \mathrm{LiI}$ and $0.2 \mathrm{I}_{2}$ gel electrolyte (G1-LiI- $\left.\mathrm{I}_{2}-2\right) ; 0.43 \mathrm{~g}$ of LiI, $0.08 \mathrm{~g}$ of $\mathrm{I}_{2}, 1.0 \mathrm{~g}$ of surfactant and $0.46 \mathrm{~g}$ of $\mathrm{H}_{2} \mathrm{O}$ were put into a vial and then into a heating bath at $80{ }^{\circ} \mathrm{C}$ for 24 hours for homogenization. Following that, the gel samples were ready for further characterization and solar performance measurements.

\section{Preparation of the solution phase samples with redox couple}

Same mole ratios of LiI, $\mathrm{I}_{2}$ and surfactant were used to prepare the electrolyte solutions. However this time, excess solvent was added (5 g). Since these samples were not in a gel phase, 24 hours in the heating bath was not necessary, 6 hours of stirring on the stirrer was enough for the homogenization. A number of solvents were tried when preparing electrolyte solutions, such as water, ethanol, acetonitrile and some combinations of the two.

\section{Fabrication of the solar cells}

First the FTO (fluorine doped tin oxide) glasses were cleaned with tap water, detergent and ethanol and were coated with a protective layer. A solution of $5 \mathrm{~mL}$ of ethanol, $0.25 \mathrm{~g}$ of $\mathrm{Ti}\left(\mathrm{OC}_{4} \mathrm{H}_{9}\right)_{4}$ and $0.5 \mathrm{~mL}$ of $\mathrm{HNO}_{3}$ were prepared and spin coated over a FTO glass electrode at $1000 \mathrm{rpm}$. The films were then calcined at $450{ }^{\circ} \mathrm{C}$ for 10 minutes. The coating process was repeated to ensure that the FTO glass was completely coated. Once completed, $0.200 \mathrm{~g}$ of $\mathrm{TiO}_{2}$ powder (>21 nm particles), 12 drops of acetic acid, 1 drop of Triton X100, $0.6 \mathrm{~mL}$ of distilled water and $0.6 \mathrm{~mL}$ of ethanol were placed in a mortar and ground 
until the mixture became smooth. Then the titania paste was spread over the pre-coated FTO glasses using a doctor blading technique and calcined at $450{ }^{\circ} \mathrm{C}$ for 1 hour. The electrodes were used as working electrodes for solar cell measurements upon sensitizing. For the sensitization, $0.024 \mathrm{~g}$ of N719 dye powder was added into $20 \mathrm{~mL}$ of ethanol to prepare a $1 \mathrm{mM}$ dye solution. The working electrodes were dipped into these solutions for 24 hours to adsorb the dye molecules. The gel electrolytes or the electrolytes, obtained in the solution phase, were placed on the dye adsorbed titania working electrode and were rested for some time to ensure an effective diffusion of the electrolyte into the pores of the titania working electrode by leaving the electrolyte over the anode for 3-4 hours until the solvent evaporated and solution became gel-like. The counter electrode was prepared by dropping 1 or 2 drops of a solution of $0.026 \mathrm{~g}$ of $\mathrm{H}_{2} \mathrm{PtCl}_{6}$ in $5 \mathrm{~mL}$ of 2-propanol, spread over a cleaned FTO glass and then calcined at $450{ }^{\circ} \mathrm{C}$ for 1 hour. The counter electrode is placed on the working electrode, like a sandwich; one must be very careful that the electrolyte does not to spread over the uncovered parts of the working electrodes.

\section{Instrumentation}

Polarized Optical Microscope (POM) images of the samples were recorded in transmittance mode by using a ZEISS Axio Scope.A1 polarizing optical microscope with a Linkam LTS350 temperature controlling stage attached to the microscope. The temperature control was performed by using a LinkamT95LinkPad temperature programmer attached to the stage. The X-ray Diffraction (XRD) pattern were recorded using Rigaku Miniflex diffractometer, which uses a high power $\mathrm{Cu}-\mathrm{K}_{\alpha}$ source operating at $30 \mathrm{kV} / 15 \mathrm{~mA}$ and a wavelength of $1.5405 \AA$ A. The measurements were carried out by spreading the samples on clean glass slides by either spin-coating or drop casting methods. The Fourier Transform Infrared (FT-IR) and Attenuated Total Reflectance-FTIR (ATR-FT-IR) spectra were recorded using Bruker Tensor 27 model FT-IR (a Digi Tect TM DLATGS detector was used with a resolution of $4.0 \mathrm{~cm}^{-1}$ in the $400-4000$ $\mathrm{cm}^{-1}$ range) and the Bruker ALPHA-P FT-IR spectrometer, which includes a diamond ATR attachment, respectively. The FT-IR measurements were carried out using the samples either by spreading or spin coating over a silicon wafer. The ATR measurements were carried out by dropping the samples onto the diamond. In order to prevent evaporation of the solvent some samples were covered with thin microscope slides. The Raman spectra were recorded using Jobin Yvon Horiba Scientific LabRam confocal Raman microscope with a $300 \mathrm{~mm}$ focal length, $1024 \times 256$ element CCD cameras, a Ventus LP 532, 50 $\mathrm{mW}$, diode pumped solid state laser. The detector collects the signals using a fiber optic cable with $600 \mathrm{~g} \mathrm{~mm}^{-1}$ grating. UV-vis spectra were recorded using a Varian Carry 5 double beam spectrophotometer. The spectra were collected with $600 \mathrm{~nm}$ $\min ^{-1}$ speed and $0.2 \mathrm{~nm}$ resolution over a wavelength range from $200 \mathrm{~nm}$ to $900 \mathrm{~nm}$ using the samples that were spin coated on the quartz windows. The AC impedance data were collected using Gamry G750 potentiostat/galvanostat with a homemade conductivity cell. The cells were made up of an FTO glass, which was scratched with a diamond cutter to break the contact between each side of the FTO. Then, the scratched line was filled with $0.01 \mathrm{M} \mathrm{KCl}$ to determine the cell constant; and following that the samples were put into the same cell to determine the conductivity of the samples using the predetermined cell constant. The solar performance measurements were carried using an AM 1.5 solar simulator with a 300 W xenon lamp, model no. 81172, Oriel. The intensity of the incoming light was adjusted to $100 \mathrm{~mW} \mathrm{~cm}^{-2}$ by using a reference silicone photodiode. Finally, the photocurrent of the cells were measured in terms of solar performances by applying external bias using a Keithley model 2400 digital source meter.

\section{Conclusions}

The lithium salts ( $\mathrm{LiCl}, \mathrm{LiBr}, \mathrm{LiI}$, and $\mathrm{LiNO}_{3}$ ) and non-ionic surfactants (such as 10-lauryl ether, $\mathrm{C}_{12} \mathrm{E}_{10}$ ) form lyotropic liquid crystalline mesophases over very broad salt concentrations in the presence of a 2-3 water/salt mole ratio. The addition of $\mathrm{I}_{2}$ into the $\mathrm{G} n$ - $\mathrm{LiI}-\#$ and $\mathrm{LiI} / \mathrm{I}_{2}$ couple into the $\mathrm{G} n$-LiX-\# (X is $\mathrm{Cl}^{-}, \mathrm{Br}^{-}$, and $\mathrm{NO}_{3}{ }^{-}$) samples produces $\mathrm{G} n$-LiI- $\mathrm{I}_{2}-\#$ and $\mathrm{G} n$-LiX\#-LiI-I ${ }_{2}$, respectively, which can be used as an LLC electrolyte and redox couple in a DSSC. Note also that the amount of water required when preparing the mesophases, is much lower than the amount of water required when preparing saturated solutions of these salts. The mesophases of the salt-surfactant can be prepared directly in the LLC phases (G1 samples) or from a solution phase by evaporating the excess solvent (G2 samples). The water content and structures of G1 and G2 samples are identical at all salt concentrations.

The infiltration of the gel into mesopores of the anode is in general challenging but the mixture of all ingredients can be introduced as a solution at which point the gelation can be carried in and over mesopores of the anode. This ensures a better contact between the anode and gel electrolyte and the cells perform much better. The best cells using $\mathrm{G} n-\mathrm{LiI}-\mathrm{I}_{2}-2$ display high open circuit voltage, as high as $0.75 \mathrm{~V}$, which is unusual in a water-based electrolyte with a decent fill factor of 0.67 .

Water molecules, in the $\mathrm{G} n$ - $\mathrm{LiCl}$ and $\mathrm{G} n$ - $\mathrm{LiNO}_{3}$, are bulk-like but in the $\mathrm{G} n$ - $\mathrm{LiI}, \mathrm{G} n$-LiI- $\mathrm{I}_{2}$, and $\mathrm{G} n$ - $\mathrm{LiBr}$, are in the hydration sphere of the ions, in which their behavior is consistent with the Hofmeister effect; the $\mathrm{Br}^{-}$ion is a water structure breaker or hydrotropic. The addition of $\mathrm{LiBr}$ to the media enhances the conductivity of the mesophase but also increases the melting point of the mesophase. Notice that the $\mathrm{G} n$ - $\mathrm{LiBr}-\mathrm{LiI}-\mathrm{I}_{2}-0.7$ has the highest recorded $V_{\mathrm{oc}}$ value of $0.81 \mathrm{~V}$ with a very good fill factor of 0.69 and of low $I_{\mathrm{sc}}$. It is likely that the high melting point of $\mathrm{G} n-\mathrm{LiI}-\mathrm{I}_{2}-\mathrm{LiBr}$ makes it difficult to infiltrate into the mesopores of the anode. The DSSC performs efficiently using the salt-surfactant liquid crystalline gelelectrolytes, but requires further investigations to improve the diffusion and conductivity of the gels, towards a finding promising alternatives to other gel and solution based electrolytes.

\section{Acknowledgements}

Authors thank to TÜBITAK under the project numbers $112 \mathrm{~T} 407$ for financial support. JB thanks to TÜBİTAK for the sabbatical 
support under 2223 program. Ö. D. is a member of the Science Academy, Istanbul, Turkey.

\section{Notes and references}

1 P. V. Kamat, J. Phys. Chem. C, 2007, 111, 2834-2860.

2 B. O'Regan and M. Gratzel, Nature, 1991, 353, 737-740.

3 A. Hagfeldt and M. Gratzel, Acc. Chem. Res., 2000, 33, 269277.

4 M. Law, L. E. Greene, J. C. Johnson, R. Saykally and P. Yang, Nat. Mater., 2005, 4, 455-459.

5 A. Hagfeldt, G. Boschloo, L. Sun, L. Kloo and H. Pettersson, Chem. Rev., 2010, 110, 6595-6663.

6 S. Mathew, A. Yella, P. Gao, R. Humphry-Baker, B. F. E. Curchod, N. Ashari-Astani, I. Tavernelli, U. Rothlisberger, K. Nazeeruddin and M. Gratzel, Nat. Chem., 2014, 6, 242-247.

7 F. Gao, Y. Wang, D. Shi, J. Zhang, M. Wang, X. Jiang, R. Humphry-Baker, P. Wang, S. Zakeeruddin and M. Gratzel, J. Am. Chem. Soc., 2008, 130, 10720-10728.

8 G. Boschloo and A. Hagfeldt, Acc. Chem. Res., 2009, 42, 18191826.

9 H. J. Snaith and L. Schmidt-Mende, Adv. Mater., 2007, 19, 3187-3200.

10 J. Wu, Z. Lan, J. Lin, M. Huang, Y. Huang, L. Fan and G. Luo, Chem. Rev., 2015, 115, 2136-2173.

11 P. V. Kamat, J. Phys. Chem. C, 2008, 112, 18737-18753.

12 Y. L. Lee and Y. S. Lo, Adv. Funct. Mater., 2009, 19, 604-609.

13 P. K. Santra and P. V. Kamat, J. Am. Chem. Soc., 2012, 134, 2508-2511.

14 M. R. Kim and D. Ma, J. Phys. Chem. Lett., 2015, 6, 85-99.

15 G. H. Carey, A. L. Abdelhady, Z. Ning, S. M. Thon, O. M. Bakr and E. H. Sargent, Chem. Rev., 2015, 115, 12732-12763.

16 H. Saito, S. Uegusa, T. N. Murakami, N. Kawahima and T. Miyasaka, Electrochemistry, 2004, 72, 310-316.

17 C. Law, S. C. Pathirana, X. Li, A. S. Anderson, P. R. F. Barnes, A. Listorti, T. H. Ghaddar and B. C. O'Regan, Adv. Mater., 2010, 22, 4505-4509.

18 K. Zhu, S. R. Jang and A. J. Frank, Energy Environ. Sci., 2012, 5, 9492-9495.

19 C. Law, O. Moudam, S. Villarroya-Lidon and B. O'Regan, J. Mater. Chem., 2012, 22, 23387-23394.

20 E. H. Kong, J. Lim, Y. J. Chang, Y. H. Yoon, T. Park and H. M. Jang, Adv. Energy Mater., 2013, 3, 1344-1350.

21 H. Choi, J. Han, M. S. Kang, K. Song and J. Ko, Bull. Korean Chem. Soc., 2014, 35, 1433-1439.

22 V. Leandri, H. Ellis, E. Gabrielsson, L. Sun, G. Boschloo and A. Hagfeldt, Phys. Chem. Chem. Phys., 2014, 16, 19964-19971.

23 H. Zhang, L. Qui, D. Xu, W. Zhang and F. Yan,J. Mater. Chem. A, 2014, 2, 2221-2226.
24 F. Bella, C. Gerbaldi, C. Barolo and M. Gratzel, Chem. Soc. Rev., 2015, 44, 3441-3473.

25 N. Yamanaka, R. Kawano, W. Kuba, T. Kitamura, Y. Wada, M. Watanabe and S. Yanagida, Chem. Commun., 2005, 740742.

26 N. Yamanaka, R. Kawano, W. Kubo, N. Masaki, T. Kitamura, Y. Wada, M. Watanabe and S. Yanagida, J. Phys. Chem. B, 2007, 111, 4763-4769.

27 R. D. Costa, F. Werner, X. Wang, P. Gronniger, S. Feihl, F. T. U. Kohler, P. Wasserscheid, S. Hibler, R. Beranek, K. Meyer and D. M. Guldi, Adv. Energy Mater., 2013, 3, 657665.

28 D. Hongberg, B. Soberats, S. Uchida, M. Yoshio, L. Kloo, H. Segawa and T. Kato, Chem. Mater., 2014, 26, 6496-6502.

29 S. J. Park, K. Yoo, J. P. Kim, J. Y. Kim, D. K. Lee, H. Kim, J. H. Kim, J. Cho and M. J. Ko, ACS Nano, 2013, 7, 4050-4056.

30 S. S. Soni, K. B. Fadadu, R. L. Vekariya, J. Debgupta, K. D. Patel, A. Gibaud and V. K. Aswal, J. Colloid Interface Sci., 2014, 425, 110-117.

31 D. Högberg, B. Soberats, R. Yatagai, S. Uchida, M. Yoshio, L. Kloo, H. Segawa and T. Kato, Chem. Mater., 2016, 28, 6493-6500.

32 Ö. Çelik and Ö. Dag, Angew. Chem., Int. Ed., 2001, 40, 38003803.

33 C. Albayrak, N. Özkan and Ö. Dag, Langmuir, 2011, 27, 870873.

34 C. Albayrak, A. Cihaner and Ö. Dag, Chem.-Eur. J., 2012, 18, 4190-4193.

35 C. Albayrak, G. Barım and Ö. Dag, J. Colloid Interface Sci., 2014, 433, 26-33.

36 G. Barım, C. Albayrak, E. Yılmaz and Ö. Dag, Langmuir, 2014, 30, 6938-6945.

37 C. Albayrak, G. Barım and Ö. Dag, Chem.-Eur. J., 2013, 19, 15026-15035.

38 M. G. Cacace, E. M. Landau and J. J. Ramsden, Q. Rev. Biophys., 1997, 30, 241-277.

39 L. Zheng, H. Minamikawa, K. Harada, T. Inoue and G. G. Cernik, Langmuir, 2005, 19, 10487-10494.

40 T. Inoue, Y. Yokoyama and L. Q. Zheng, J. Colloid Interface Sci., 2004, 274, 349-353.

$41 \mathrm{H}$. Isci and W. R. Mason, Inorg. Chem., 1984, 24, 271-274.

42 K. Kaya, N. Mikami, Y. Ugadawa and M. Ito, Chem. Phys. Lett., 1972, 16, 151-153.

43 L. Andrews, E. S. Prochaska and A. Loewenschuss, Inorg. Chem., 1980, 19, 463-465.

44 P. H. Svensson and L. Kloo, Chem. Rev., 2003, 103, 16491684 . 